The innovative surgical and the conservative treatments of ocular diseases by Victor Boleslaw Wicherkiewicz (1847-1915)*

Authors: Dieter Schmidt, Andrzej Grzybowski

Submitted:

14. May 2016

Published:

Volume:

Issue:

14. May 2016

3

Keywords:

2

DOI:

Wicherkiewicz, ophthalmology,therapy of ocular diseases, surgery 10.17160/josha.3.2.122 


\title{
The innovative surgical and the conservative treatments of ocular diseases by Victor Boleslaw Wicherkiewicz (1847-1915)*
}

\author{
Dieter Schmidt(1), Andrzej Grzybowski ${ }^{(2)}$
}

\begin{abstract}
Background: To call attention to the surgical procedures by Boleslaw Wicherkiewicz.

Methods: Evaluation of Wicherkiewicz's important publications which were published in German journals.

Results: Victor Boleslaw Wicherkiewicz's published about 300 papers in several languages, mainly in Polish and German. His innovative surgical methods were concerned with several ocular diseases, such as trichiasis, distichiasis, ectropion, lid replacement, free skin transplantation, corneal staphyloma, lid coloboma, eye muscle -, and cataract surgery. His conservative treatments were concerned with corneal diseases, and glaucoma. In addition, he studied the effect of Cocaine on the eyes. He reported on congenital ectropium uveae, and on bilateral anophthalmus. In addition, Wicherkiewicz described a bilateral epibulbar dermoid combined with auricular anomalies that was later called Goldenhar syndrome. He constructed an instrument for measuring the extent of the orbit, and he introduced a clearly arranged, sterilisable metal box with ophthalmological instruments and medicaments for emergency situations.
\end{abstract}

\section{Boleslaw Wicherkiewicz' s biography}

He was born on July 7th, 1847 in Kcynia (Exin, located around $100 \mathrm{~km}$ to north-east from Poznan). Wicherkiewicz studied medicine in Berlin at the "Kaiser-Wilhelm-Akademie". His studies were interrupted by the German-French war in 1870/71, in which he participated in the medical services in several battles and at the siege of Paris. After the war he terminated his medical studies in Berlin. In 1872, he graduated at the University of Berlin. The theme of the thesis was:"On sarcomas and their occurrence in the mediastinum". Then, he removed to Breslau and worked as assistent in a hospital at the Pediatric-Surgical Department in Breslau; later he specialized in ophthalmology at the Eye Clinic in Breslau as assistent (Director: Richard Foerster), and afterwards, at the Eye Clinic in Wiesbaden (Director: Alexander Pagenstecher). In 1877

\footnotetext{
(1)Prof. Dr. Dieter Schmidt

Univ.-Augenklinik

Killianstr. 5

D-79106 Freiburg, Germany

(2) Department of Ophthalmology,

Poznan City Hospital, Poznan, Poland

Department of Ophthalmology, University of Warmia and Mazury, Olsztyn, Poland
}

he made an informative trip to London, Paris, Heidelberg, Leipzig, and Halle. Being well educated in ophthalmological proceedings, he went home to Poznan and founded a private clinic and an ophthalmological hospital for poor people, there. Soon this hospital with 80 beds became the biggest ophthalmic department on Polish lands at this time ${ }^{1,2}$. His most important colleague in Poznan was Emil von Behring who was awarded with the Nobel prize in $1901^{3}$.

In recognition of his personal engagement in treating ophthalmic diseases of his patients, Wicherkiewicz received from the Prussian minister of education, in 1894, the title "Professor". In 1895 he was appointed director of the Ophthalmological Clinic at the Jagiellonic University in Krakau by the Austrian government. Wicherkiewicz founded the first Polish ophthalmological monthly journal („Postep Okulistiyczny“). Wicherkiewicz was a member of several Ophthalmological and other scientific societies, i.e. Ophthalmological Society Heidelberg, French Ophthalmological Society, Society of German scientists and physicians. He was president of the Polish national committee for international medical congresses (Paris, Madrid, Lissabon). He was elected Dean of the medical 


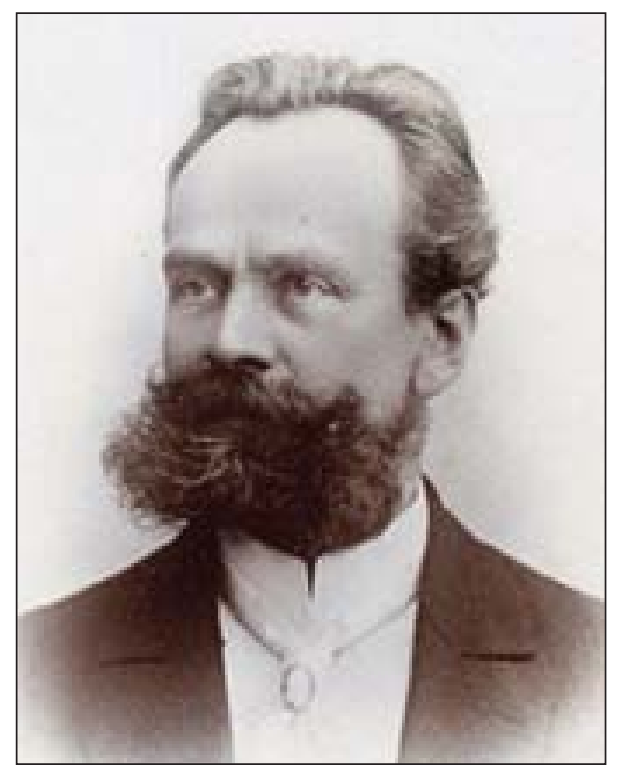

Boleslaw Wicherkiewicz

faculty at the University in Krakau. He was awarded with the knightly order of the papal St. Georg order and with the officer's cross from the Austrian Red Cross. He became honorary doctor at the Leuven (also Louvain) University in Belgium. Together with his colleagues, he founded in 1909 the Polish Medical Weekly Journal „Nowiny lekarskie“. During the First World War he was elected president of the Polish Samaritan Society. He also was president of the Krakau volunteer rescue society for as long as 18 years.

Wicherkiewicz died on January 7th, 1915 in his 68th year of life. ${ }^{4,5,6,7,8,9,10}$

\section{Introduction}

Wicherkiewicz's publications reflect his innovative surgical methods he developed in different ocular diseases such as his efficient and functioning glaucoma operations. He successfully operated deformities of the eyelids and he revealed much practice in cataract surgery. In addion, Wicherkiewicz reported on his results treating ocular diseases conservatively. His pharmacological experiences with Cocaine, Morphium in ocular anesthesia, or with Eserine, Pilocarpine in chronic glaucoma patients, or with Atropine in inflammatory intraocular diseases were demonstrated in several publications. In addition, Wicherkiewicz reported on several case studies with congenital anomalies, such as anophthalmos, dermoid of the conjunctiva or of the corneo-scleral margin, and he informed on his observations of retinal diseases and ocular tumours. He designed new practical, handsome instruments for ophthalmologists. He knew how to convict a person who simulated amblyopia or amaurosis. Wicherkiewicz founded an eye hospital for poor people in Poznan that emphasizes his great social engagement.

\section{INNOVATIVE SURGICAL TREATMENTS}

\section{Glaucoma surgery}

Surgery of glaucoma with the equatorial "sclerotomia cruciata posterior" (1912, 1913) ${ }^{11,12}$ : The lattice sclerotomy or "sclerotomia cruciata posterior" was carried out after anesthesia with $1 \%$ Cocaine solution and Epinephrine was injected into the subconjunctiva. Then, Wicherkiewicz incised the conjunctiva in a meridional direction at the equator level (Fig. 1), then, he performed 10$12 \mathrm{~mm}$ long deep meridional scleral incisions and several cross sections. After this sclerotomia he closed the conjunctival wound with several sutures (Fig. 2). Wicherkiewicz reported that the intraocular pressure increased postoperatively, but after a massage of the globe of about two minutes, the eye pressure became normal.

Wicherkiewicz found that in old people the sclera could be thickened. The scleral elasticity is reduced with a thick sclera that may cause an increased resistance resulting in an increased intraocular pressure. Wicherkiewicz postulated that the sclera rigidity causes an impaired communication between the suprachoroidal and Tenon's space. The vessels, predominantly the vortex veins might be occluded or narrowed by the thickened sclera leading to an increased intraocular pressure. In the suprachoroidal space a lymphatic congestion may occur.

Wicherkiewicz had successfully operated about 100 patients with glaucoma with this method.

\section{Comment:}

This new surgical technique of a posterior sclerotomy by Wicherkiewicz was helpful in his glaucoma patients and showed better results - according to him - than with 
an anterior sclerotomy, developed by de Wecker $(1871)^{13}$ that was modified by Mauthner $(1877)^{14}$, and practised by Hock $(1878)^{15}$ and Plenk $(1878)^{16}$. Wicherkiewicz did not report on long-term results of his patients. But from his experience with his surgical method in about 100 patients, carried out without complications, one can guess that long-term good results had been observed in his patients.

The Iridectomy technique $(1883,1901)^{17,18}$ :

Wicherkiewicz explained his technique with a small hook: after a small limbal incision of $2 \mathrm{~mm}$ length, he introduced a blunt small silver hook into the anterior chamber.

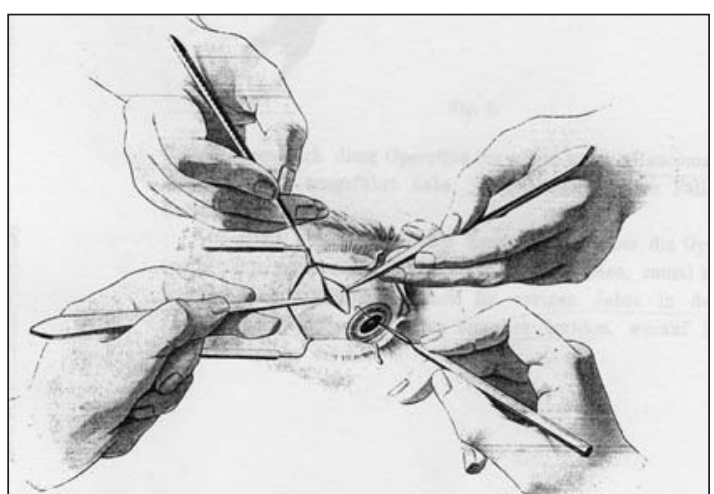

Fig. 1. After anesthesia with $1 \%$ Cocain solution, epinephrine was injected into the subconjunktiva; Meridional incision of the conjunctiva

He turned the tip of the hook behind the iris in such a way that he could draw the iris margin into the scleral wound. In this place he cut out a piece of iris tissue. The advantage of the small iris hook was the painless procedure in contrast to grasping the iris with a forceps that was painful.

An unusual event in surgery of acute glaucoma $(1882)^{19}$ :

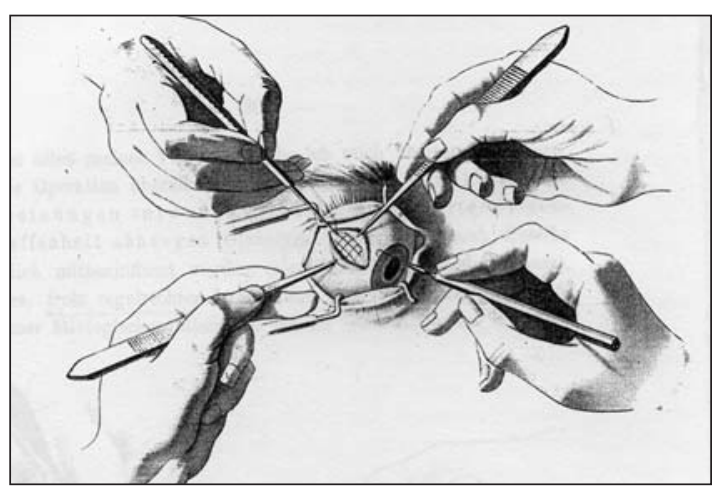

Fig. 2. 10-12 $\mathrm{mm}$ long meridional deep scleral incisions together with deep cross sections

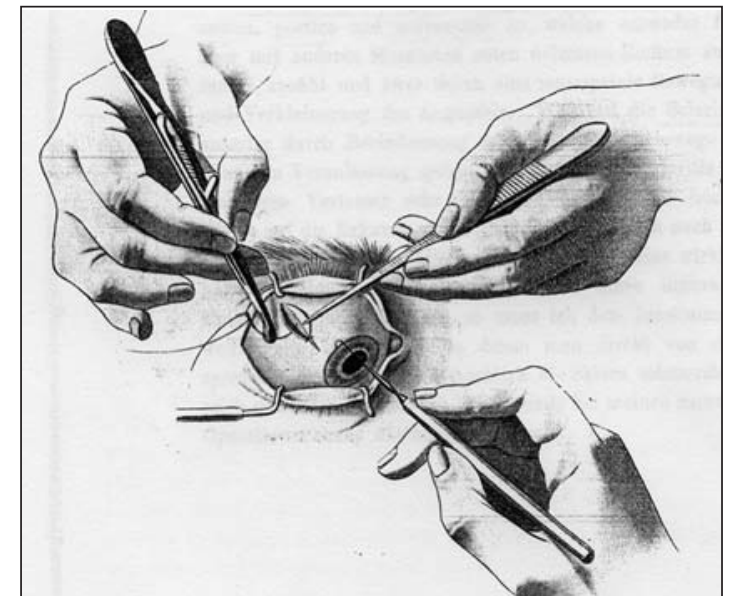

Fig. 3. Closure of the conjunctival wound with several sutures

A 50-year-old woman with acute glaucoma was sucessfully treated with $1 / 2 \%$ Eserine eye drops. In addition, Wicherkiewicz carried out an iridectomy after reduction of the high intraocular pressure. During the procedure the ocular tension increased. The operation was aggravated due to restlessness of the patient. Postoperatively, Wicherkiewicz treated the eye with Eserine ointment. The next day, when he removed the bandage, he found the hard, yellow lens nucleus close to the eye, as sign of the surgical complication. He continued treating with Eserine eye drops and found normal ocular pressure in the postoperative time.

\section{Lid-Operations (plastic surgery) (trichia- sis, distichiasis, lower lid-ectropion, lid-re- placement, free skin transplantats, lid coloboma)}

Surgical procedure for treating scar defective lid positions (1882 and 1886)

Wicherkiewicz operated a 43-year-old woman with a long-standing ectropium of the upper and lower lids with lagophthalmos due to scars after an erysipelas facial inflammation. He excised the lid scars and covered the defect with a free skin transplant from the upper arm. The operation led to a successful healing of the transplants. Wicherkiewicz also operated a 25-year-old man with scars of the lids after facial burns in the same way. However in this patient a skin infection delayed the healing process, a slight ectropion resulted. In the discussion of this publication, Wicherkiewicz mentioned the complications of such a surgical procedure and quoted the experience with three patients by Wilhelm v. 
Zehender who had reported in 1879 on late scar shrinkage of the transplant after an initial successful healing. Therefore, a second operation $^{22}$ had been necessary. After this publication in 1882, Wicherkiewicz reported in 1886 his new surgical procedure that he carried out in two steps. In eight patients with scar defective lid positions, he first excised the lid scar and used a compressive bandage on the wounds for several days (first step). After this compression, when no hemorrhaghes occurrred any more, he transplanted the skin of the upper arm into the lid wounds (second step). He called this procedure "secondary free skin transplantation" and observed good results of the healing processes. The advantage of this proceeding was the avoidance of transplant casting caused by hemorrhages.

\section{Surgical procedure of lid replacement $(1891)^{23}$ :}

Wicherkiewicz also reported on the replacement of an upper lid that was completely destructed by a lid carcinoma in an 80 year-old woman (Figs.4,5). He removed the whole upper lid together with the tumour. Then, he made two skin incisions being in divergent and downward direction of the lower lid, forming a triangular skin flap (A) (Fig. 5). He drew this lower lid skin patch over the eye

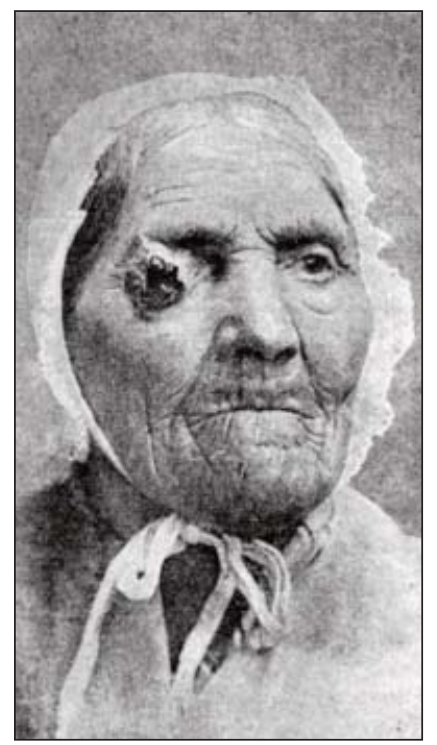

Fig.4. 80-year-old woman with an ulcerative carcinoma of her right upper lid

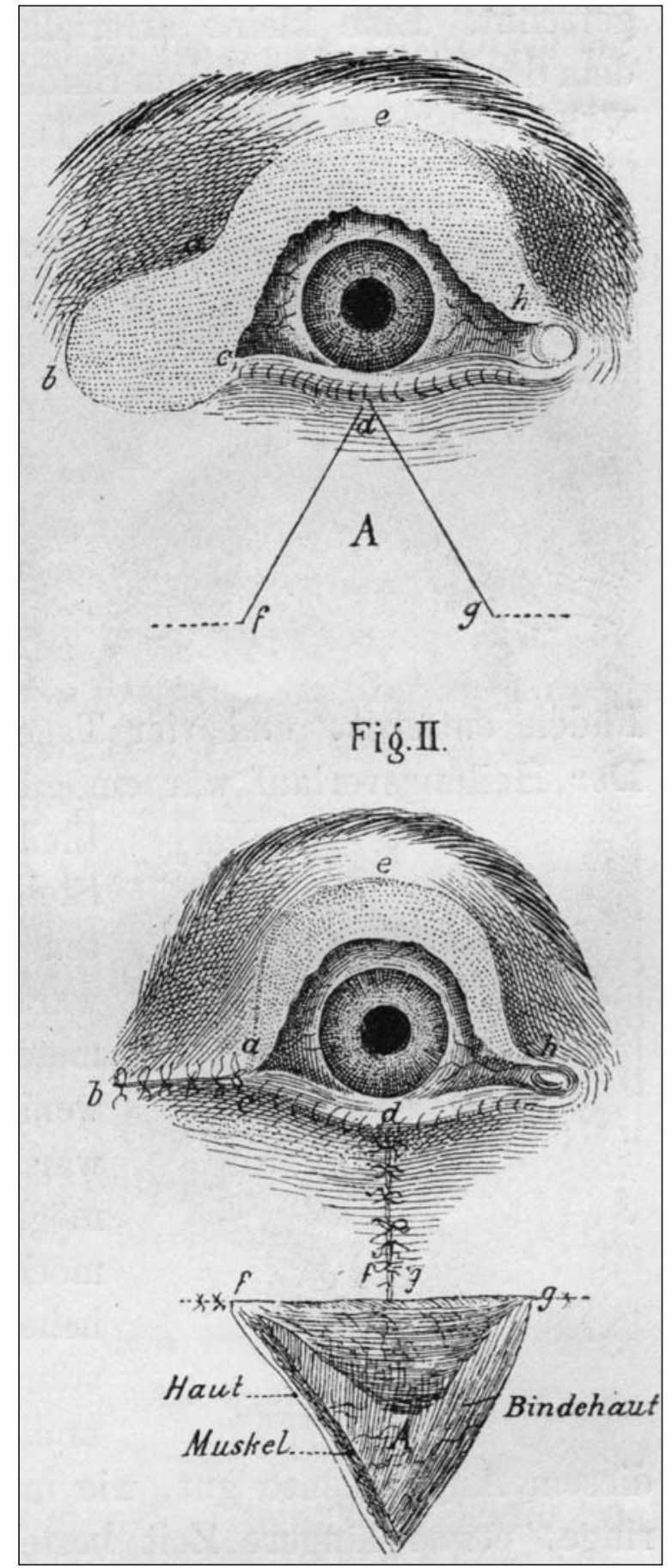

Fig. 5. (upper picture) After excision of the upper lid with removal of the tumor, a large triangular skin defect resulted. (lower picture) Wicherkiewicz made two divergent downward directed incision into the lower lid skin that formed a triangular skin flap (A). 


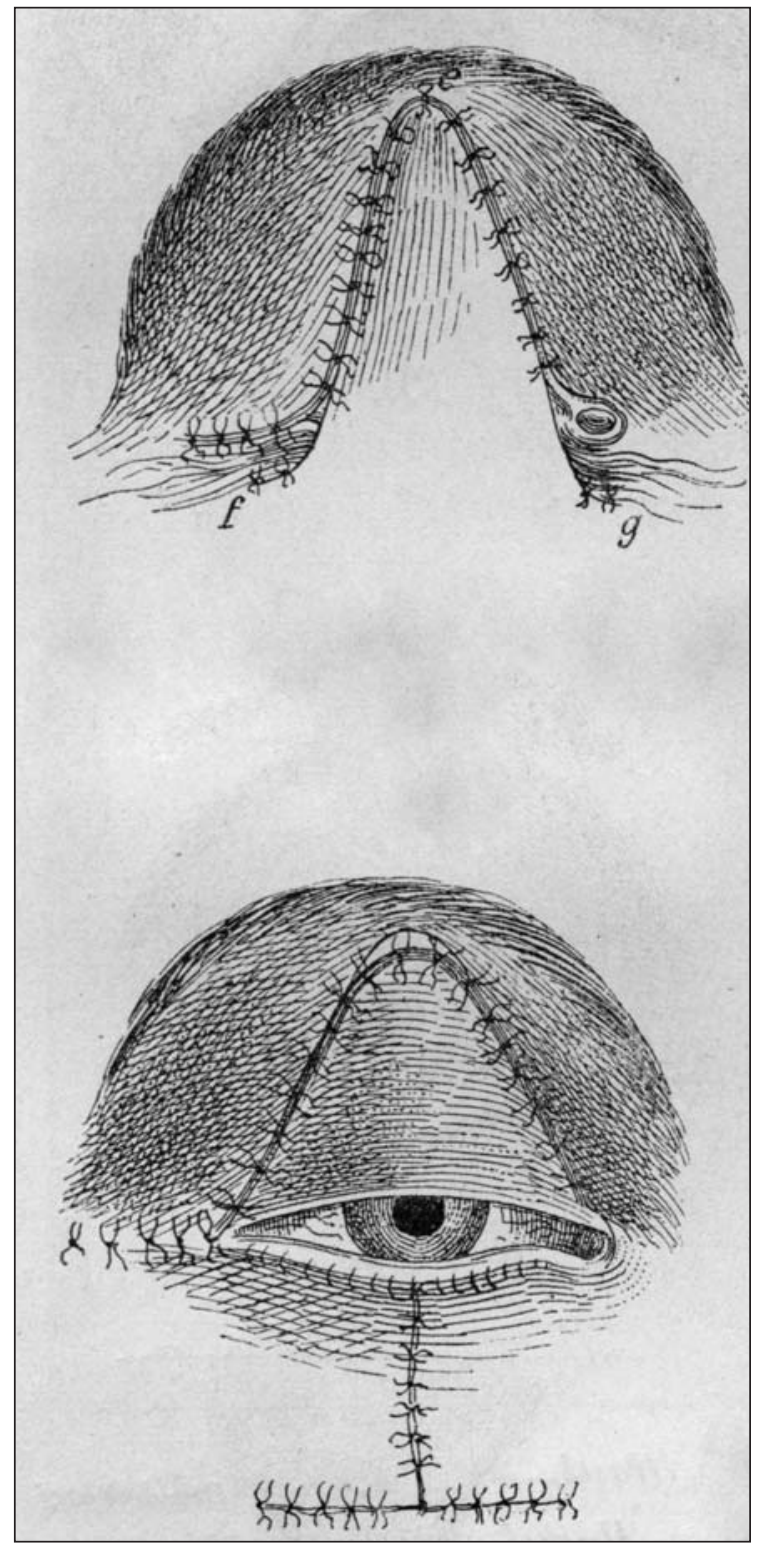

Fig. 6. (upper picture): Wicherkiewicz drew the lower lid skin patch over the eye and sutured it at the wound margins of the upper lid. Six days later, he separated the skin bridge over the eye (lower picture) for release of the eye and sutured it at the wound margins of the upper lid (Fig.6). Six days later, he separated the skin bridge over the eye (lower picture) for release of the eye.

\section{Surgical treatment of a lower lid ectropion $(1899)^{24}$ :}

An ectropion of the lower lid was repaired as follows: below the margin of the lower lid (4-6 mm), Wicherkiewicz made a skin incision parallel to the lid edge. Then, he separated the lid skin from the muscle tissue of the lid above the tarsus and drew the skin upwards and pulled the laid open tarsus downwards. Then, he pierced a needle through the upper margin of the skin wound below the upward positioned orbicularis muscle, then he led the needle through the convex tarsus margin and above the upward located orbital part of he orbicularis muscle and after this downwards into the lower orbital margin through the skin outwards. Two additional sutures were led in a similar way. The three threads were knotted over a cotton plug. After this procedure a regular lid position resulted.

Surgical procedure against trichiasis und distichiasis $(1888,1912)^{25}$ :

Wicherkiewicz initiated surgery by pushing a horn plate under the lower lid. With a Graefe knife (Fig.7), he separated the lid margin resulting in an anterior lid part with the skin, muscle and cilias (eye lashes) and a posterior lid part with the tarsus and conjunctiva.

Then Wicherkiewicz cut the upward

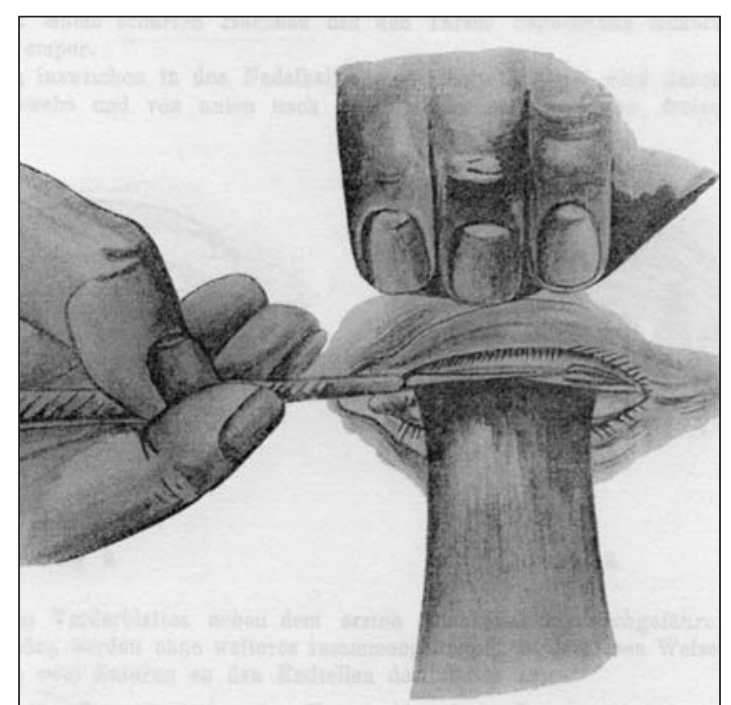

Fig. 7. Separation of the upper lid into an anterior and and a posterior lid part with a Graefe knife 


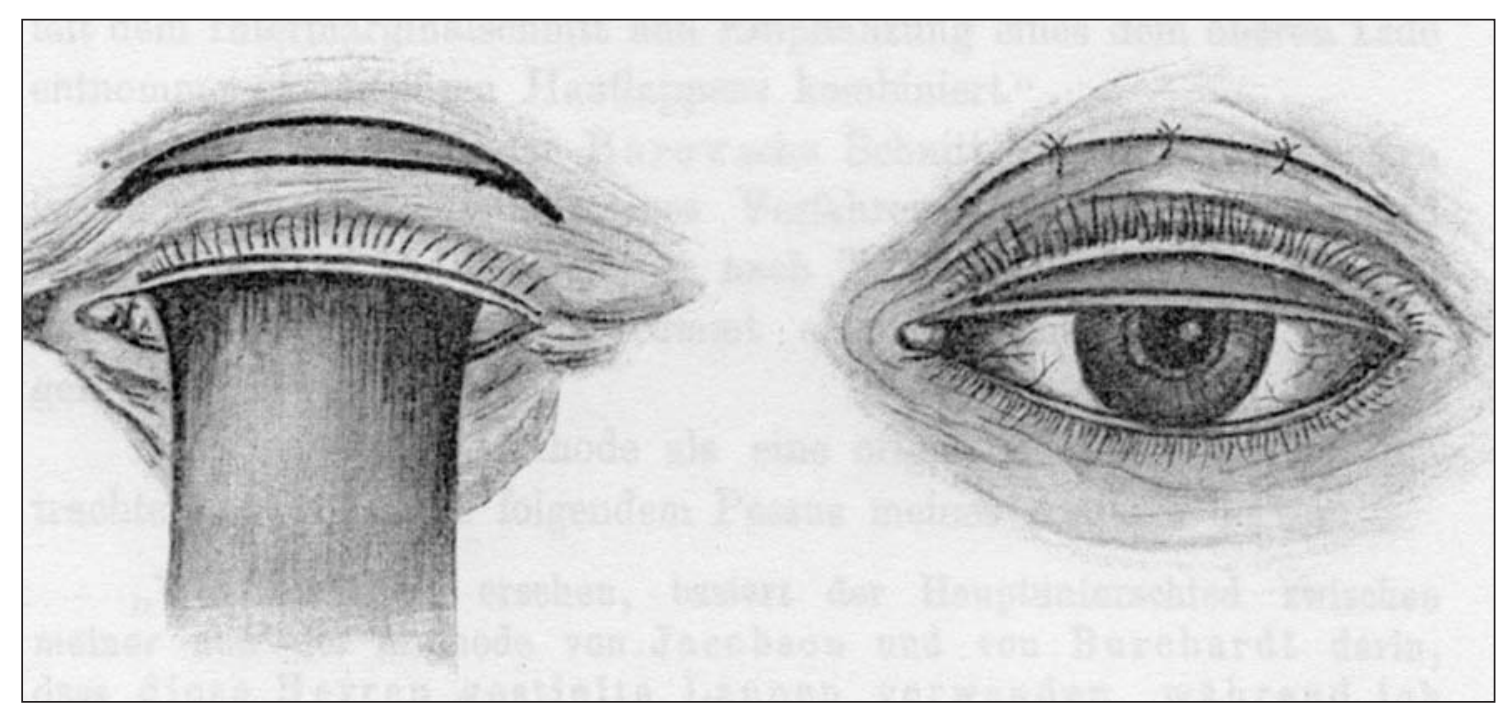

Fig. 8. Oval incision (3 $\mathrm{mm}$ distant to the lid margin) of the anterior part on the level of the tarsus top

drawn anterior lid part on the level of the tarsus top with a scalpel on the horn plate.

In a second step (Fig.8), Wicherkiewicz attached the tarsus with 3 sutures on the surrounding tissue, resulting in an upward drawn shortened anterior lid part.

The upward drawn anterior part was then fixed with 3 single sutures

In a third step, Wicherkiewicz inserted a free small skin transplant into the intermarginal space and covered it with tinfoil and an antiseptic dressing consisting of iodoform gauze. Both eyes were then bandaged. Different to former surgical methods with helved skin flaps, Wicherkiewicz used a free skin transplant which healed successfully.

\section{Surgical treatment of small lid colobomas $(1904)^{26}$ :}

The coloboma in the middle part of the upper lid of a 25-year-old man was operated on. At first, Wicherkiewicz separated the lid skin superiorly and sidewards of the coloboma in two leafs in a similar way as described in his trichiasis surgery. Then, he covered the lid coloboma with a free skin transplant that he sutured with the anterior skin part of the incised lid. Wicherkiewicz had cut out the skin transplant from the most superior part of the upper lid.

\section{Cataract Surgery (1880) ${ }^{27}$}

Three patients who were 59, 70 and 73 years old were successfully treated with ice bandages after cataract surgery. The cold dressing was comfortable and alleviating. Wicherkiewicz covered the eye with the ice bandage for about one hour. In case of lang-standing ocular pain he continued with this cold treatment for several hours. In case of an ocular inflammation (iritis or irodocyclitis), he treated additionally with a small linen patch, soaked with 5\% carbol solution.

A new procedure of immature cataract surgery $(1885,1886,1889)^{28,29,30}$ :

Remaining lens remnants in the anterior chamber after cataract surgery may occlude the pupillary area. In a 46-year-old patient with an immature cataract, Wicherkiewicz washed the lens remnants out with an undine that was filled with $1 \%$ boric acid solution. Wicherkiewicz had designed an undine that caused a constant, even fluid output for removing the small lens particles at the end of a cataract operation. The slow flow did not cause a high flow pressure in contrast to an injection with a syringe.

Wicherkiewicz used the undine (Fig.9) by closing the opening (A) of the undine with his index and introduced the tip (B) of the undine into the anterior chamber and behind the iris. When he lifted his index the flow of the solution was slow and without pressure in such a way that the lens particles could be removed from the posterior or anterior eye 


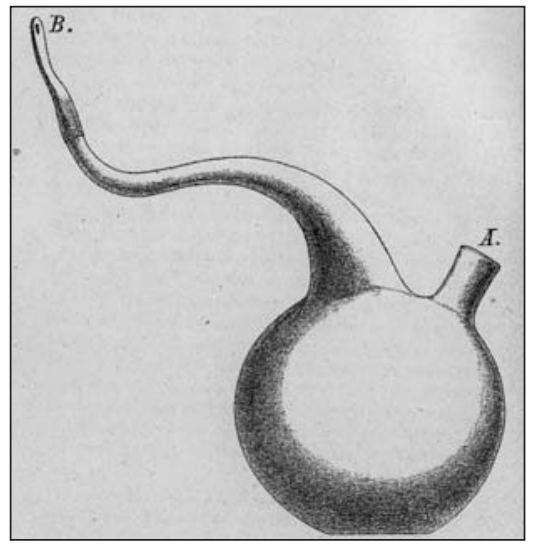

Fig. 9. Undine after Wicherkiewicz, for intraocular washing

chamber. He had had successfully operated 18 patients with this procedure.

The use of a new bandage after cataract surgery $(1886)^{31}$ :

It is important to use a firm ocular bandage after cataract surgery because of the danger of an ocular infection or of a wound rupture. Potators have an increased risk for such complications.

Wicherkiewicz did not recommend the open wound treatment. He used a bandage with thick layers of iodoform gauze and cotton. The bandage was soaked with sublimate gauze. Both eyes were dressed and after 4 days were uncovered. The eyes were further treated with diluted sublimate solution into the conjunctiva. Then, Wicherkiewicz fastened a new bandage with flanell for 2-3 days. After this consequent treatment in the postopertive time, Wicherkiewicz did not observe an ocular infection.

Description of the lens capsule opening in cataract surgery $(1889)^{32}$ :

Wicherkiewicz emphasized to remove the lens capsule together with all lens remaining masses to avoid the development of after-cataract. In case of a thickened lens capsule, the removal of it can be carried out with a special small sugical forceps (Fig.10). Wicherkiewicz designed a forceps with 4 or 5 small teeth that was favourable for his surgery.

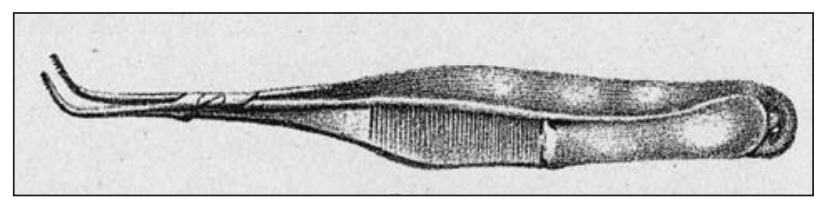

Fig. 10. Capsular forceps designed by Wicherkiewicz
The absorbable effect of iodine potassium after cataract surgery (1898)33:

Wicherkiewicz treated patients who showed remaining lens remnants after cataract surgery with iodine potassium. With this treatment he observed a fast absorption. The dosage of this medication of 3-5 gr. a day, rarely he prescribed a higher dosage up to $10 \mathrm{gr}$. a day.

Open wound treatment after cataract surgery $(1904)^{34}$ :

Wicherkiewicz developed a paper hollow bandage to avoid any pressure on the eye. With this bandage no pressure was exerted and the eye movements were not restricted. The protecting paper was adhered to the front, temple, nose, and cheek without touching the eyelashes, creating a hollow cavity above the eye. After cataract surgery, Wicherkiewicz ordered this special paper bandage for 4-5 days. It was useful to use it particularly in children. Wicherkiewicz adjusted the bandage in several intraocular operations, such as iridectomies. He had treated about 150 patients successfully with this paper hollow bandage with less infections compared with patients treated with compression bandages.

\section{Postoperative glaucoma development (1904) ${ }^{35}$ :}

In six patients an increased ocular pressure occurred after cataract surgery. Wicherkiewicz treated them with Eserine and Pilocarpine. In a 75-year-old man and in a 53-year-old woman, a second iridectomy was necessary to lower the intraocular tension. In a 67-year-old man a vitreous prolapse occurred during his cataract operation. Pilocarpine did not lower the pressure. Wicherkiewicz had to perform a second iridectomy that decreased the pressure.

\section{Surgery of the Sclera (1880) ${ }^{36}$ :}

A 34-year-old woman, who had fallen ill with typhoid fever in 1872 and 1976, suffered from a unilateral painful scleritis. The conjunctiva was chemotic. A circumscribed area of the inflammation part was thickened and vascularized.

Wicherkiewicz made a 12 to $15 \mathrm{~mm}$ long conjunctival incision and scraped the subconjunctival soft spongy, bleeding tissue out with a small sharp spoon. The eye was afterwards covered with an ice pad and an antiseptic bandage. The eye was then treated with a $1 \%$ 
zinc solution. After this operation, the patient had no ocular pain any more.

\section{Surgery of corneal staphyloma (1884, 1906) $^{37}$ :}

Wicherkiewicz operated a six months old infant who suffered from blennorrhoea neonatorum and who revealed a distinct leucoma adhaerens of the right eye. He initially made an iridectomy. Two weeks later, he removed the staphyloma (staphylotomy). With this procedure he tapped the staphyloma wall with a Bowman-needle, causing flowing off of aqueous humour. Then, he cut out an oval part of the staphyloma wall (4-6 $\mathrm{mm}$ in diameter) with Cooper-scissors. With a compression bandage he covered the operated eye. A distinct improvement was observed, half a year later. The staphyloma was much smaller and the transparent corneal area was enlarged.

\section{Conservative Treatments ${ }^{38}$}

Treatments with medicaments (mydriatic, miotic agents) in cataract patients (1889):

In case of central lens opacification Wicherkiewicz recommended Cocaine eye drops. He argued that Cocaine has no influence on the accommodation. He reported on a 64-year-old man with central catararct who had a better near vision after treatment with Cocaine eye drops. Patients with peripheral lens opapifications were not treated with Atropine- oder Homatropine eye drops because of an increased dazzling. In contrast, he treated with $1 / 2 \%$ Pilocarpine. He reported on a better vision in a 67 -year-old man after treatment with these eye drops.

The importance of Antipyrine treatment in eye diseases (1891) ${ }^{39}$ :

Wicherkiewicz recommended Antipyrine that showed an antipyretic and an antiseptic effect in patients with inflammatory ocular diseases, i.e. in corneal diseases, irodocyclitis, trigeminus neuralgia, and conjunctivitis. Trachomatous corneal infiltrations decreased with the Antipyrine treatment. Pain due to episcleritis or scleritis were reduced with Antipyrine. A purulent dacryocystitis improved. However, an exact observation during treatment is necessary, because of the intoxication danger.
Conservative treatment of glaucoma patients $(1896)^{40}$ :

Patients with chronic glaucoma were treated with Eserine or Pilocarpine. In case of painful Eserine treatment, Wicherkiewicz injected Morphium subcutaneously. He claimed that patients suffering from an acute glaucoma should be early treated with an iridectomy. In patients, younger than 40 , he recommended de Wecker's „sklerotomy“. This procedure was carried out by introducing two lancets in two opposite positions at the limbus into the anterior chamber close to the pupillary margin and then, he withdrew the instruments. Postoperatively he treated with Pilocarpine eye dops. In case of an insufficient intraocular pressure lowering, he treated with an iridectomy after some days.

Historical remarks on the medication of glaucoma $(1901)^{41}$ :

When Wicherkiewicz was an assistent in Wiesbaden 1875/76, he had treated glaucoma patients with Calabarbean-extract. Later, he used Eserine eye drops, but they were painful and had sometimes caused hemorrhages. These side effects was not observed in the treatment with Pilocarpine eye drops, which were introduced in 1875 by Weber from Darmstadt. Patients with chronic glaucoma were treated by Wicherkiewicz with mixture of low percentage Eserine, $\mathrm{Pi}$ locarpine und Cocaine. This combination of eye drops was also helpful in patients with an acute glaucoma.

\section{The effect of Cocaine in ophthalmology $(\mathbf{1 8 8 5})^{42}$}

Wicherkiewicz used Cocaine in every operation, i.e. in cataract surgery, iridectomy, chalazion operation, probing of dacryocystostenosis, strabismus surgery, lid operations, staphyloma operations and enucleations.

Depent on the procedure, he used $2 \%, 5 \%$ or $10 \%$ solutions. Wicherkiewicz administered Cocaine ointment in patients with an ocular inflammation. He never observed visual deterioration caused by Cocaine in his patients. After dripping Cocaine 4 or 5 times into the eye, the iris was insensitive. Even in strabismus surgery the muscles became insensitive by higher concentrations of Cocaine. In case of an enucleation, Wicherkiewicz injected Cocaine subconjunctivally. If the patient suffered from pain in spite of these injections, 
Wicherkiewicz injected Morphium subcutaneously in addition.

The harmful effect of Cocaine $(1885)^{43}$ :

In the literature the dangerous Cocaine effect had been reported in patients with a parenchymatous keratitis. But Wicherkiewicz concluded that sublimate and not only Cocaine might have caused serious side effects.

The use of Cocaine in ophthalmic surgery $(1888)^{44}$ :

Wicherkiewicz observed in cataract surgery that a $5 \%$ Cocaine solution caused corneal opacification after dripping three or fourtimes.

\section{Cocaine intoxication $(1888)^{45}$ :}

Wicherkiewicz reported on a patient who developed cramps of the limbs, a frequent pulse, irregular respiration and enlarged pupils for many hours after Cocaine eye drops.

\section{The functional importance of eye muscle division $(1908)^{46}$ :}

A patient who refused an enucleation of a blind shrinking eye ball was treated by Wicherkiewicz with resection of the recti eye muscles. The globe showed constriction caused by the external eye muscles which diminished after muscular resection and the pain disappeared. Wicherkiewicz carried out this procedure successfully in six additional patients instead of an enucleation.

\section{Treatment of trachoma $(1886)^{47}$ :}

A trachomatous conjunctivitis was treated by squeezing the conjunctival granules with the nails of both thumbs and in addition, by scraping out and later by washing out the conjunctiva. After drying the conjunctival surface he powdered it with boric acid-tannin acid powder for several weeks. In case of a thickened trachomatous pannus he treated with galvanocautery. Boric acid-tannin acid powder was also used in patients with chronic blennorrhea and with phlyctenular inflammation of the conjunctiva and cornea or in patients with lid eczematosis or in those with inflammation of the outer eye due to skrofulosis.

\section{Corneal diseases ${ }^{48}$}

The recurrent traumatic corneal neuralgia (1898): After healing of traumatic corneal lesions, some patients suffered from pain even after closure of the wound by epithelialization with a smooth corneal surface, without opacification. Patients with these kind of pain were successfully treated with Morphium injections. Wicherkiewicz reported that patients with an extensive corneal lesion had less pain in comparison to patients with small corneal defects. He presumed that in the large defect the corneal nerves were transected, however in small lesions nerves are not destructed, they were irritated.

Corneal moulds infection (1900 ${ }^{49}$ :

A 23-year-old patient showed a serious hypopyon keratitis of her right eye with yellow-white infiltration of the cornea after foreign body injury with mud. Treatment with Atropine, $10 \%$ Xeroform ointment, and warm boric acid bandages did not change much the inflammatory process. After removing the yellow-white hard infiltrative masses with a sharp spoon and a knife, and treatment with Hydr. oxyd. flavum and Xeroform the inflammation improved.

\section{Treatment of patients with keratoco- nus (1905) ${ }^{50}$}

Wicherkiewicz argued that a keratoconus may occur by disposition of the corneal tissue and additionally by an increased intraocular pressure. He observed that patients with keratoconus partly close their myopic eyes for a better vision. The pressure of the upper lid on the peak of the conus displaces it. He treated patients with keratoconus by cauterization of the conus peak and by iridectomy. In addition, he administered Pilocarpine.

\section{Congenital anomalies ${ }^{51,52}$}

Congenital anophthalmos $(1878,1880,1910)$ :

Wicherkiewicz reported on infants with anophthalmos. In a 1/2-year-old child the inferior lids were swollen due to fluctuating orbital cysts. The analysis of the cyst's fluid revealed a content of protein content of 6,2\% (Albumin, Globulin und Fibrinogen). Wicherkiewicz found a cleft between the maxillary sinus and the orbit. 
Description of a dermoid of the limbus in a 20-year-old patient (1882) ${ }^{53}$ (Fig.11)

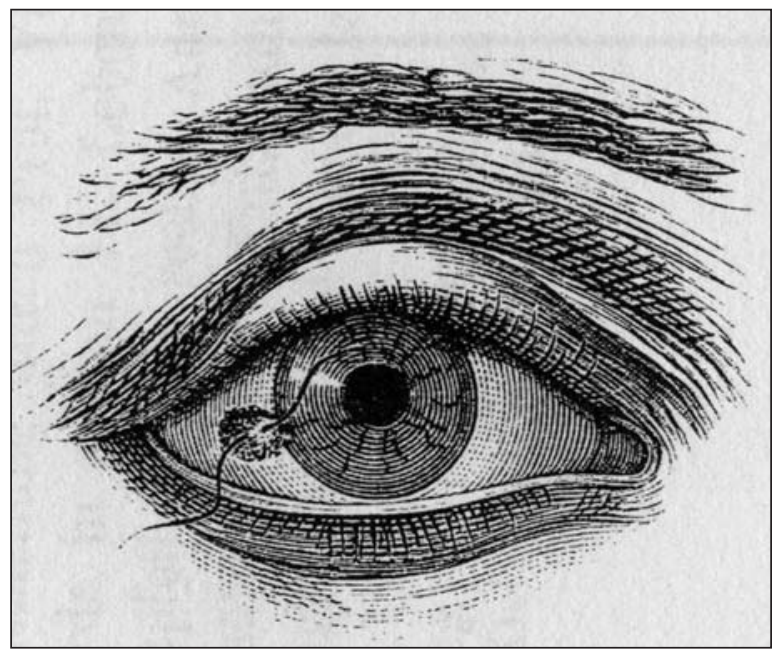

Fig. 11. Dermoid of the conjunctia

Bilateral auricular appendiges and bilateral corneo-scleral dermoids (1884) ${ }^{54}$ :

An 11-year-old girl revealed congenital anomalies of the auriles and eyes. Wicherkiewicz removed the dermoids of the limbus (Fig.12) which had caused an astigmatism. The description of these auricular and ocular congenital anomalies were later termed Goldenhar syndrome ${ }^{55,56}$.

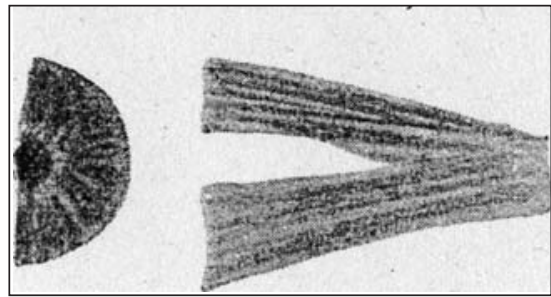

Fig. 13. Congenital tailed tendon of the internal rectus muscle

13. Traumatic ocular lesions $(1894)^{58,59}$ Two patients with old intraocular foreign bodies were described who showed chronic ocular inflammations. After antiphlogistic treatment metallic iris foreign bodies were found and removed by Wicherkiewicz.

Report on the right eye injury by broken glass in a 4-year-old child: The cornea revealed opacifications and was vascularised. Several months later the unhurt other eye developed a diffuse interstitial keratitis. The father of the child had been treated for his syphilis infection. After treatment of the child's keratitis parenchymatosa, the corneal changes improved with mercurial treatment.

Traumatic loss of the lens (1913) ${ }^{60}$

A 52-year-old man with a perforating ocular injury caused by a cowhorn-shove was examined several weeks after the accident. Wicherkiewicz found a pigmented sclera ectasia, a sharply bordered iris coloboma and an absent lens.

\section{Tumours of the fundus.}

Report on a 12-yearold boy with an intraocular, globe filling tumour $(1879)^{61}$.

The tumor had

Anomalous insertion of the internal rectus muscle tendon (1907) ${ }^{57}$ :

A 19-year-old man with a congenital divergent strabismus revealed two insertions of the muscle tendon (Fig.13). Wicherkiewicz resected $4 \mathrm{~mm}$ of the internal muscle and operated the external rectus muscle by tenotomy. After this surgery the eye showed a regular position. grown into the orbit. After orbital exenteration, no recurrence occured within 8 weeks of observation, but after 2 further weeks.

Metastasising chlorosarcoma (1882)62: Boleslaw Wicherkiewicz reported on 28-yearold man with anemia and headache who showed a right progressive exophthalmos and
The authors Emil von Behring and 
a left one that developed after a while. In addition, a papilledema, increasing within some weeks was diagnosed. Both eyes went blind after a short period, and a left facial paresis developed. He also revealed a sternal tumor swelling. The patient died after two months. The autopsy revealed a tumour which grew from the sphenoidal sinus into the nasal cavity, orbit, and the middle cranial fossa.

Sternal and liver metastases were found. Because the tumour had a green colour and the tumour chloric content was increased, the authors named this malignoma chlorosarcoma.

\section{Retinal diseases}

On the pernicious influence of sunlight on the eyes $(1893)^{63}$ :

A 9-year-old boy who complained in the evening after solar irradiation on headache, feeling of pressure in the eyes and he had fever. The examination revealed reduction in visual acuity, colour sense disturbances, and concentric constriction of the visual field. Wicherkiewicz ordered dark treatment with porcelain chambers on the eyes and injected Strychnine. Two weeks later the patient had normal vision.

Another patient, 49-years old, had a solar irradiation during his work. Later, he developed severe headache, ocular scintillating, and dizziness. He revealed a slight conjunctivitis, colour vision disturbances and a concentric constriction of the visual fields. Wicherkiewicz treated the patient successfully with Antipyrine drops.

\section{Description of Retinitis punctata albescens $(1906)^{64}$}

The patient had normal visual acuity but he was nightblind. The retina revealed small flecks with recess of the macular area. Consanguinity of the parents was assumed. No treatment is possible.

\section{New Instruments}

Porcelain chambers on the eyes for dark treatment $(1889)^{65}$ :

Enamel layered porcelain chambers on the eyes for dark treatment were initially developed. But because of the porcelain weight, Wicherkiewicz used hard rubber. Three different sizes suitable to the orbital size were manufactured.
New measure instrument for the orbit $(1894)^{66}$ :

Wicherkiewicz designed an instrument for measuring the width and height of the orbit (Fig.14). This instrument was also suitable for measuring the size in millimeter of pathologically changed organs.

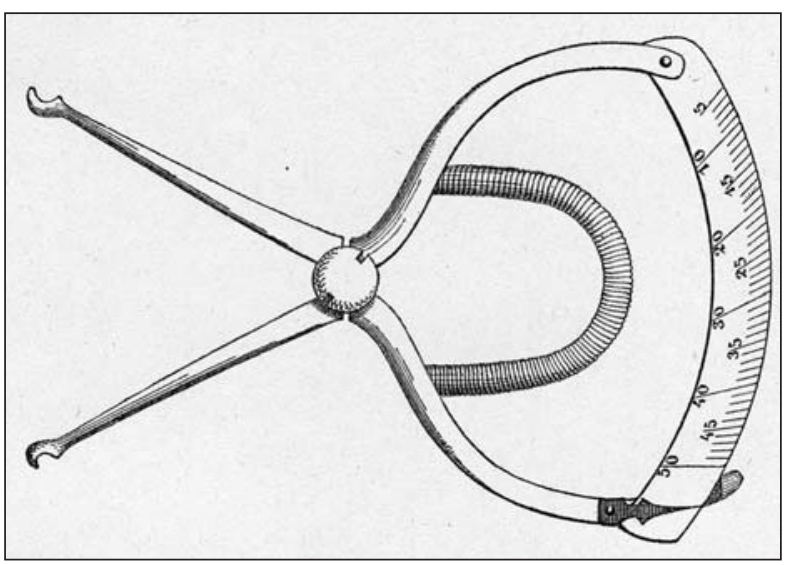

Fig. 14. Instrument for measuring the orbital size after Wicherkiewicz

Metallic sterilisable emergency chest for ophthalmological instruments (1905) ${ }^{67}$ :

A clearly arranged metallic chest containings four separated quare boxes (size: 17,5 times 12 times $15 \mathrm{~cm}$ ), was designed by Wicherkiewicz. The first box contained an ophthalmoscope and three small ointment jars within one glass tray, in the second box small dropper bottles for Pilocarpine, Atropine, cocaine and a glass undine with Boric acid solution were placed. In the third box airtight lockable case for gauze strips and convex lenses (+ 15 und $+20 \mathrm{dpt}$ ) were placed. In the fourth box cotton swabs and small cloths were placed. The metallic chest was sterilisable with vapour for 30-40 minutes.(Fig.15) 


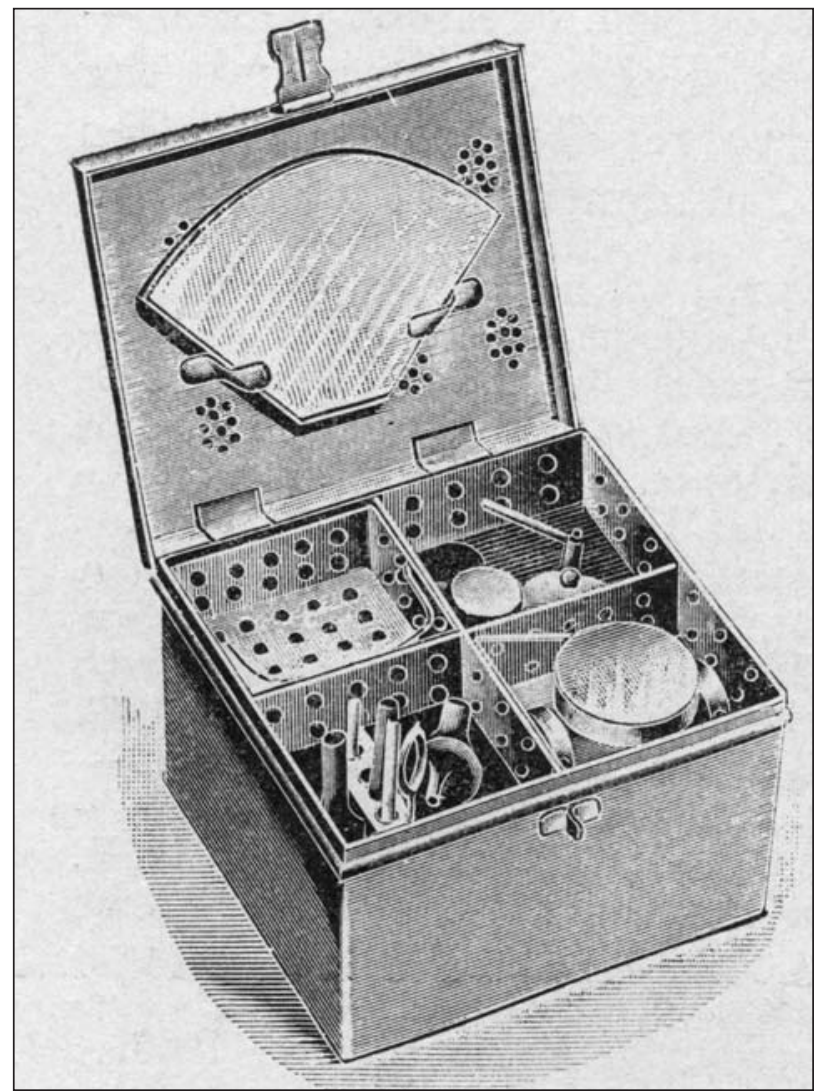

Fig. 15. Sterilisable metallic chest containing ophthalmological instruments and medicaments

\section{Simulation}

Methods to convict a person with simulated amblyopia (1893)68:

In case of a simulated right eye amblyopia, Wicherkiewicz put on spectacles with a weak convex lens in front of the right eye and of the left eye (dependent from a refraction anomaly) a lens with $+10 \mathrm{dpt}$. - or higher. Then, the person was asked to read the letters of a Snellen table in a distance of 5 or 6 meters. Wicherkiewicz reported that he was successful in most situations in such a way that the person could read the letters. was important to ask the patient to read quickly and to read immediately.

In case of simulated amaurosis, Wicherkiewicz recommended the following test: The person was asked to close both eyes. The investigater should hold with one finger of his left hand on the closed lids of the person. With an ophthalmoscope of the right hand, the investigator illuminates alternatively quickly successively both eyes. The investigated person was asked telling the illuminated eye quickly. Wicherkiewicz reported that in most cases the simulated person said that the pretended amaurotic eye had seen the light, particularly if the healthy eye was illuminated before several times quickly, successively.

\section{Conclusion}

Boleslaw Wicherkiewicz was certainly most influential and most important ophthalmologist living in Polish lands at the turn of 19 century. He contributed to major ophthalmic topics with more than 300 papers in different languages, mainly in Polish and German. He described innovative surgical techniques in glaucoma treatment, plastic surgery and cataract surgery. He devised many original instruments, including capsular forceps and undine for intraocular washing. At his time, he was internationally recognized and invited as a speaker and chairman to major international ophthalmic conferences. References to his works can be easily found in many contemporary textbooks and articles. Julius Hirschberg, famous German ophthalmologist of historian of ophthalmology wrote about him: „Anybody who knew Wicherkiewicz closely will attest to his amiablity. Anybody who follows the literature will recognize his indefatigable activity though he was frequently sick and had to overcome certain handicaps. Wicherkiewicz achieved great success for his countrymen, for the Polish ophthalmic literature and for the Polish culture in general". ${ }^{69}$ Edward Jackson, prominent American ophthalmologist, who is best remembeerd with cross-cylinder test wrote on Wicherkiewicz: „But few European writers have contributed so much to the literature of ophthalmology in the last score of years, or so much that was original; and upon such a wide range of subjects". ${ }^{70}$ With his many original developments, Wicherkiewicz was certainly an important contributor to the international Ophthalmology. 


\section{References}

1. Grzybowski A., Bolesław Wicherkiewicz i jego słynny szpital okulistyczny, Kronika Miasta Poznania: Szpitale 2007; 4: 255-261. 2. Grzybowski A., Bolesław Wicherkiewicz and his famous ophthalmology hospital, Annals of Poznań City: Hospitals, 2007; 4: 255-261.

2. Wicherkiewicz, Bolesl.; Einige Erfahrungen über den therapeutischen Wert und die Anwendungsweise des Cocaines in der Augenheilkunde. Centrbl. prakt. Augenheilkd. 1885; 9: 85-89; 115-118; Centrbl. prakt. Augenheilkd. 1888; 12: 30-31

3. Grzybowski A, Wilhelm H. Little known ophthalmic interests of Emil von Behring, the first Nobel Prize Laureate in Medicine or Physiology. Acta Ophthalmol. 2013; 91:381-4.

4. Grzybowski A. Forgotten achievements of Polish retinal research in international ophthalmology. Acta Ophthalmologica 2012; 90:193-198.

5. Majewski, K.W. Professor Boleslaus Wicherkiewicz. Klin. Monatsbl. Augenheilkd. 56(1916), S. 289-292.

6. Grzybowski, A. Dieter Schmidt,D. Boleslaw Wicherkiewicz - interesting contributor to European ophthalmology. Cogan Ophthalmic History Society; The 25th Annual Meeting; March 30-31 (2012); Washington DC/Bethesda USA

7. Hirschberg, J. Boleslaw Wicherkiewicz (geb.am 17.7.1847 zu Exin, gest. am 7.12.1915 zu Wien), Centralbl. prakt. Augenheilkd. 25 (1916), S. 24-26

8. Schmidt, D., Grzybowski, A. Das wissenschaftliche Werk des bedeutenden polnischen Augenarztes Viktor Boleslaw Wicherkiewicz (1847-1915). Tagung der Deutschen Ophthalmologischen Gesellschaft, 110. Tagung (20.9.2012), Estrel, Berlin

9. Talko,J. Offene Korrespondenz. Posen, Berufung von Prof. Bol. Wicherkiewicz an die Universit.t Krakau, Klin. Monatsbl. Augenheilkd. 34 (1896), S. 180-181

10. Wicherkiewicz,B. B.Wicherkiewicz †. Zeitschr. Augenheilkd. 35 (1916), S. 374-376

11. Wicherkiewicz Boleslaw. Discussion zu Kuhnt's Vortrag über die Trepanation beim Glaukom (,sclerotomia cruciata posterior"). Ber. Dtsch. Ophthalmol. Ges. Heidelberg, 37. Meeting, Klin. Monatsbl. Augenheilkd. 1912; 50: 254 .

12. Wicherkiewicz B. Weitere Erfahrungen über die Gittersklerotomie. Ber. Dtsch. Ophthalmol. Ges. 1913; 39: 196-204

13. Wecker,L.de Die Sklerotomie als Glaukomoperation. Klin. Monatsbl. Augenheilkd. 9 (1871), S. 305-310

14. Mauthner,L. Aphorismen zur Glaukomlehre. Geschichte der Sclerotomie. Arch. Augenheilkd. 7 (1878), S. $165-186$

15. Hock, J. Acht Sclerotomien nach der v. WeckerMauthner'schen Methode. Arch. Augenheilkd. 7 (1878), S. $408-424$

16. Plenk,F. .ber einige Glaucom-Sclerotomien. Arch. Au- genheilkd. 7 (1878), S. 424-425

17. Wicherkiewicz, B. Zur Iridectomietechnik. Centrbl. prakt. Augenheilkd. 1883; 7: 33-36

18. Wicherkiewicz B. Zur Iridectomie-Technik. Centralbl. prakt. Augenheilkd. 1901; 25: 200-201

19. Wicherkiewicz B. Ein seltener Heilungsverlauf einer Glaukom-Iridectomie nebst einigen Betrachtungen über traumatische Linsentrübungen. Klin. Monatsbl. Augenheilkd. 1882; 20: 181-191; Centrbl. prakt. Augenheilkd. 1882; 6: 244; Centrbl. prakt. Augenheilkd. 1882; 6: 401-402 20. Wicherkiewicz B. Zur Beurteilung des Wertes stielloser Haut-Transplantationen für die Blepharoplastik. Klin. Monatsbl. Augenheilkd. 1882; 20: 419-448

21. Wicherkiewicz, Boleslaw. Über secundäre stiellose Hauttransplantation und ihre Verwertung für die Blepharoplastik. Graefe's Arch. Ophthalmol. 1886; 32: 189-224 22. Carl Wilhelm von Zehender, C.W. von .ber EktropionOperation durch Transplantation gro.er Hautstucke. Klin. Monatsbl. Augenheilkd. 17 (1879), S. 213-222

23. Wicherkiewicz B. Über eine neue blepharoplastische Methode zur Deckung des Substanzverlustes nach Entfernung einer das ganze Lid einnehmenden Geschwulst. Klin. Monatsbl. Augenheilkd. 1891; 29: 20-25

24. Wicherkiewicz Boleslaw. Zur operativen Technik des Ektropion des Unterlides. Beitr. Augenheilkd. 1899; 4: 480-484

25. Wicherkiewicz, B. Über meine Trichiasis- und Distichiasisoperation nebst einigen kritischen und historischen Bemerkungen. Centrbl. prakt. Augenheilkd. 1888; 12: 94-95; Graefes Arch. Ophthalmol. 1912; 80: 439-453; 26. Wicherkiewicz B. Über ein geeignetes Verfahren gegen kleinere Lidcolobome. Arch. Augenheilkd. 1904; 50: $166-169$

27. Wicherkiewicz Boleslaw. Über die Eis-Anwendung nach Star-Extractionen. Klin. Monatsbl. Augenheilkd. 1880; 18: 4-20; Centrbl. prakt. Augenheilkd. 1880; 4: 155 28. Wicherkiewicz B. Über ein neues Verfahren unreife Stare zu operieren, nebst Beitrag zur Augen-Antiseptik. Referat zur Publikation in: Klin. Monatsbl. Augenheilkd. 1885; 23: 478-493); Centrbl. prakt. Augenheilkd. 1885; 9: 476; Centrbl. prakt. Augenheilkd. 1889; 13: 170-171

29. Wicherkiewicz B. Über einen geeigneten Dauerverband nach Staroperationen. Centrbl. prakt. Augenheilkd. 1886; 10: 353-355

30. Wicherkiewicz B. Über das geeignetste Verfahren der Kapseleröffnung behufs Starentfernung. Klin. Monatsbl. Augenheilkd. 1889; 27: 169-178; Centrbl. prakt. Augenheilkd. 1889; 13: 213-214

31. Wicherkiewicz B. Über einen geeigneten Dauerverband nach Staroperationen. Centrbl. prakt. Augenheilkd. 1886; 10: 353-355

32. Wicherkiewicz B. Über das geeignetste Verfahren der Kapseleröffnung behufs Starentfernung. Klin. Monatsbl. Augenheilkd. 1889; 27: 169-178; Centrbl. prakt. Augenheilkd. 1889; 13: 213-214

33. Wicherkiewicz B. Zur resorbierenden Wirkung des 
Jodkali bei Staroperationen. Wochenschr. Ther. Hygiene Auges 1898; 50: 1

34. Wicherkiewicz B. Zur Frage der offenen Wundbehandlung nach Staroperationen. Klin. Monatsbl. Augenheilkd. 1904; 42: 222-238

35. Wicherkiewicz B. Du glaucome post-opératoire (après l'opération de la cataracte) Ann. Oculist. 1904; 132: 5-30 36. Wicherkiewicz, B. Zur operativen Behandlung der Scleritis. Centrbl. prakt. Augenheilkd. 1880; 4: 309-315 37. Wicherkiewicz B. Über eine vereinfachte Operation des Kornealstaphyloms. Centrbl. prakt. Augenheilkd. 1884; 8: 404; Klin. Monatsbl. Augenheilkd. 1906; 44: 32-34 38. Wicherkiewicz B. Was haben wir von der Anwendung mydriatischer und myotischer Mittel bei fixen Trübungen brechender Medien zur Verbesserung der Sehfähigkeit zu erwarten? (Internat. Klin. Rundschau 1889, Nr. 13). Centrbl. prakt. Augenheilkd. 1889; 13: 436-437 39. Wicherkiewicz B. Über die Bedeutung des Antipyrins als eines Heilmittels in der Okulistik. Allgem. Wien. Med. Zeitung 1891; 35: 368

40. Wicherkiewicz B. Zur Etiologie und Behandlung des Glaukoms. Klin. Monatsbl. Augenheilkd. 1896; 34: 161-170 41. Wicherkiewicz B. Einige Worte über die medicamentöse Behandlung des Glaucoms. Klin. Monatsbl. Augenheilkd. 1901; 39: 554-558

42. Wicherkiewicz, Bol. Zur schädlichen Wirkung des Cocaines. Centrbl. prakt. Augenheilkd. 1885; 9: 368-370 43. Wicherkiewicz, Bol. Zur schädlichen Wirkung des Cocaines. Centrbl. prakt. Augenheilkd. 1885; 9: 368-370

44. Wicherkiewicz, Bolesl. Beiträge zur Cocaineintoxication. Therapeutische Monatshefte November 1888; Centrbl. prakt. Augenheilkd. 1888; 12: 446.

45. Wicherkiewicz, Bolesl. Beiträge zur Cocaineintoxication. Therapeutische Monatshefte November 1888; Centrbl. prakt. Augenheilkd. 1888; 12: 446.

46. Wicherkiewicz B. Über die kosmetische, funktionelle und prophylaktische Bedeutung der Durchschneidung sämtlicher Recti des Augapfels. Wien. Med. Wochenschr. 1908; 58: 338-339

47. Wicherkiewicz B. Zur Augentherapie. Klin. Monatsbl. Augenheilkd. 1886; 24: 492-494

48. Wicherkiewicz B. Über recidivierende traumatische Hornhautneuralgie. Wien. Klin. Wochenschr. 1889, 11: 814-816

49. Wicherkiewicz B. Über die Schimmelpilzerkrankung der Hornhaut. Arch. Augenheilkd. 1900; 40: 361-307

50. Wicherkiewicz B. Einiges über den primären Hornhautkegel. Zeitschr. Augenheilkd. 1905; 13. 93-103

51. Wicherkiewicz, Boleslaw. Beitrag zur Casuistik des bilateralen congenitalen Anophthalmus. Klin. Monatsbl. Augenheilkd. 1878; 16: 162-166; Centrbl. prakt. Augenheilkd. 1880; 4: 434.

52. Wicherkiewicz B. Über einen seltenen Fall von Anophthalmus congenitus mit Lidzysten. Klin. Monatsbl. Augenheilkd. 1910; 48: 187-191

53. Wicherkiewicz, B. Einige Betrachtungen über soge- nannte Bulbuswarzen. Centrbl. prakt. Augenheilkd. 1882; 6: 13-18

54 . Wicherkiewicz, B. Fall von beiderseitigem Corneoscleraldermoid. Centrbl. prakt. Augenheilkd. 1884; 8: 19-22 55. Goldenhar, M. Associations malformatives de l'oeil et de l'oreille, en particulier le syndrome dermo.de pibulbaire - appendices auriculaires - fistula auris congenita et ses relations avec dysostose mandibulo-faciale. $J$. Génét. Hum. 1952 1: 243-282.

56. Schmidt,D. Neuroparalytische Keratitis bei der Dysplasia oculo-auricularis (Franceschetti-Goldenhar-Syndrom, auch Goldenhar-Gorlin-Syndrom) in: Photophobie bei Augenkrankheiten des Kindes- und Jugendalters. Verlag Dr. K.ster, Berlin 2008):81-83.

57. Wicherkiewicz B. Über eine abnorme Insertion des Rectus internus. Klin. Monatsbl. Augenheilkd. 1907; 45: 200-201

58. Wicherkiewicz B. Pseudogumma iridis auf traumatischer Basis. Klin. Monatsbl. Augenheilkd. 1894; 32: 277286

59. Wicherkiewicz B. Über die durch Trauma entstandene Keratitis parenchymatosa und die Rechtsfrage. Klin. Monatsbl. Augenheilkd. 1912; 50: 95-102

60. Wicherkiewicz B. Traumatische Ausstoßung der Linse aus dem Augapfel. Centralbl. prakt. Augenheilkd. 1913; 37: 108-109

61. Wicherkiewicz. Ein Fall von Glioma retinae. (Przeglad Lekarski 1879; No. 34, 35) Reference Centrbl. prakt. Augenheilkd. 1879; 3: 112.

62. v.Behring E, Wicherkiewicz B.. Ein Fall von metastaischem Chlorosarcom. (Berl. Klin. Wochenschr. 1882; Nr. 33) Reference Centrbl. prakt. Augenheilkd. 1882; 6: 510. 63. Wicherkiewicz B. Über den verderblichen Einfluss des Sonenlichtes auf das Auge. Int. Klin. Rundschau (Wien) 1893; 7: 62-66

64. Wicherkiewicz B. Retinitis punctata albescens. Klin. Monatsbl. Augenheilkd. 1906; 44: 539.

65. Wicherkiewicz B. Demonstration eines neuen Modells der Augenkammern für Dunkelkuren. Ber. Dtsch. Ophthalmol. Ges. Heidelberg 1889; 20: 84-85

66. Wicherkiewicz B. Posen. Ein neuer Orbitalmesser. Klin. Monatsbl. Augenheilkd. 1894; 32: 365-367

67. Wicherkiewicz B. Ein neuer sterilisierbarer Metallkasten mit augenärztlichen Utensilien. Klin. Monatsbl. Augenheilkd. 1905; 43: 236-238

68. Wicherkiewicz B. Beitrag zu den Entdeckungsmethoden einseitig simulierter Amblyopie und Amaurose. Klin. Monatsbl. Augenheilkd. 1893; 31: 134-136.

69. Hirschberg J., The history of ophthalmology, J.P. Wayenborgh Verlag, Bonn 1982.

70. Jackson E. Wicherkiewicz B, In: The American Encyclopedia and Dictionary of Ophthalmology, ed. By C.A. Wood, Chicago, 1921, p. 14023. 